\title{
New Age Umbanda: Axé and Energy in the Context of the Religious Transformations
}

\author{
Amurabi Oliveira iD https://orcid.org/0000-0002-7856-1196 \\ Federal University of Santa Catarina \\ amurabi_cs@hotmail.com \\ Felipe Boin (iD https://orcid.org/0000-0001-6751-6093 \\ Federal University of Santa Catarina \\ fbboutin@gmail.com
}

\begin{abstract}
The transformations in Afro-Brazilian religions have been the central focus of extensive literature in the fields of anthropology and sociology of religion, emphasizing both ritualistic and liturgical changes, as well as in terms of the public. In this work we analyse the phenomenon of the incorporation of elements of New Age in some Umbanda temples in the city of Florianópolis (Brazil), analysing how this process occurs and what it reveals to us in terms of the transformations of AfroBrazilian religions. The research demonstrates that this articulation occurs mainly with the use of alternative therapies in Umbanda temples and the substitution of some aspects of Afro-Brazilian religions, such as ritual animal sacrifice, with new elements.
\end{abstract}

Keywords: Umbanda, New Age, new religious movements

Słowa kluczowe: Umbanda, New Age, nowe ruchy religijne

Topics related to Afro-Brazilian cults have extensively occupied the literature in the fields of anthropology and sociology of religion in Brazil, paying special attention to the processes of transformations through which these religions have passed in recent years, as well as to the deep heterogeneity existing between them. ${ }^{1}$ This implies

${ }^{1}$ R. Motta, As variedades do espiritismo popular na área do Recife: ensaio de classificação, "Boletim da Cidade do Recife" 1977, no. 2, pp. 97-114. 
recognizing the process of re-africanization ${ }^{2}$ taking place in countless houses of worship $^{3}$ in Brazil, as well as the elaboration of new practices through dialogue with other religious traditions. ${ }^{4}$ Among these new religious arrangements, we are interested in discussing the encounter between Umbanda and New Age elements.

The New Age is as a heterogeneous phenomenon that does not present itself as an organized movement. Elements such as the flow of identities and an errant character, both from the religious and cultural points of view, stand out. Even elements of a fragmentary character, appear as the foundations of the New Age. Amaral points out that the heirs of the counterculture with their proposals of alternative communities comprise the New Age movement. ${ }^{5}$ It is also possible to identify a discourse of self-development based on therapeutic proposals, mystical experiences and holistic philosophies, besides the discourse of the contact of an individual with its "essence." Bringing together aspects of many different religiosities, these elements create a "kaleidoscopic religiosity." 6

Specialized literature has helped us to construct a more complex view of the religious experiences in Afro-Brazilian cults, trying to unveil the subtle paths traced by the orixás ${ }^{7}$ and the povo de santo ${ }^{8}$ in their processes of differentiation. Despite the progress of research, little has been discussed about the relationship between Umbanda and New Age, which goes beyond what has been termed the "Esoteric Umbanda."

Esoteric Umbanda, as one of the facets of Umbanda is understood within the Umbanda terreiros as a valid strand and does not detract from the essential teachings of the religion. The foundations of Esoteric Umbanda were shaped by W.W. da Matta e Silva, the author of nine works on the subject. Due to the term "esoteric," it is common to make a trivial approximation of the Esoteric Umbanda with what we understand here as New Era Umbanda. Thus, it is important to point out that although temples incorporate the denomination of Esoteric Umbanda, they do not necessarily perceive themselves as included in the phenomenon of New Age, constituting a secluded tradition of this phenomenon, since Esoteric Umbanda does not refer to a type of esoterism in Umbanda. ${ }^{9}$

The fragmentary character of the New Age is identified as a phenomenon of postmodernity ${ }^{10}$ pointing to a scenario in which institutionalized religions and their

2 J.R. Prandi, O Brasil com Axé: candomblé e umbanda no mercado religioso, "Estud. av., São Paulo" 2004, no. 18(52), pp. 223-238.

3 The native term is terreiro for the temples of Afro-Brazilian religions.

${ }^{4}$ A. Oliveira, "É Tudo Energia"- A Nova Era e a Umbanda em diálogo, "REVER" 2016, no. 16(2), pp. $92-107$.

${ }^{5}$ L. Amaral, Carnaval da alma: Comunidade, essência e sincretismo na Nova Era, Petrópolis 2000.

${ }^{6}$ Ibidem, p. 15.

${ }^{7}$ Native term for the gods in the Afro-Brazilian religions.

${ }^{8}$ In a literal translation it means "people of saint," which refers to the community of practitioners of Afro-Brazilian religions.

9 J. Carneiro, E. Carneiro, Umbanda Esotérica não é Esoterismo na Umbanda, "Revista Brasileira de História das Religiões" 2017, no. 10(28), pp. 113-124.

10 A.N.Terrin, Nova Era: A religiosidade do pós-moderno, São Paulo 1996. 
dogmas have failed, giving rise to manifestations marked by free association and experimentation, where each person seeks his own religious and mystical framework.

Although the religious base is the Umbanda - and here we understand religion as a set of cultural keys and beliefs that establish symbols and moral values for its practioners - exploring the encounters between Umbanda and New Age elements means discussing a proposal that allows countless possibilities of combination which seem to be randomly chosen. We seek to contribute to this field, starting from a particular case that arose in the middle of the mapping of the African matrix temples in Florianópolis, in which amidst the diversity of self-denominations that emerged we were struck by the fact that one of them assumed itself to be a "New Age Holy Umbanda."11 Other temples also conduct a dialogue with the New Age phenomenon, but they do not assume this denomination in the mapping. Here we analyse exclusively the material obtained from two temples, which have a set of characteristics that make it possible to classify them as New Age Umbanda.

We organize the text from the following axés: a) analysis of the relationship between Afro-Brazilian religions and New Age; b) specificities present in the religious field of Florianópolis; c) analysis of the two explanatory cases that emerged in the mapping of temples; d) final considerations.

\section{New Age's axé}

The literature dealing with the New Age phenomenon in Brazil has continually reaffirmed the fluid and heterodox character of the New Age, ${ }^{12}$ indicating the continuous process of performative incorporation of diverse cultural elements in its symbolic arsenal. But as Magnani ponders:

Even with the appreciation of indigenous traditions and closer contact with the ayahuasca $[\ldots]$ neo-esoterism in Brazil maintained a universal rather than a local character: much more frequent were references to the Indians of the North American plains, Castañeda, Incas, Siberian shamanism - not to mention the presence of European esotericism, Oriental philosophies, the mystery cults of Classical Antiquity, the Wicca tradition, Celtic paganism, and so on. ${ }^{13}$

${ }^{11}$ I.B. Leite, Territórios do Axé: religiões de matriz africana em Florianópolis e municipios vizinhos, Florianópolis 2017.

12 J.G.C. Magnani, Mystca Urbe: um Estudo Antropológico Sobre o Circuito Neo-Esotérico na Metrópole, São Paulo 1999; idem, O Brasil da Nova Era, Rio de Janeiro 2000; idem, O circuito neo-esotérico, [in:] As religiões no Brasil, F. Teixeira, R. Menezes (eds.), Petrópolis 2006, pp. 161-173; L. Amaral, Sincretismo em movimento: o estilo nova era de lidar com o sagrado, [in:] A nova era no Mercosul, M.J. Carozzi (ed.), Petrópolis 1999, pp. 47-79; idem, Carnaval da alma ..., op. cit.; idem, Um espirito sem lar: sobre uma dimensão nova era da religiosidade contemporânea, [in:] Circuitos infinitos, O.G. Velho (ed.), São Paulo 2003, pp. 27-58; A. Oliveira, A Nova Era com um Jeitinho Brasileiro: O Caso do Vale do Amanhecer, "Debates do NER" 2011, no. 12, pp. 67-96; idem, A Nova Era com Axé: umbanda esotérica e esoterismo umbandista no Brasil, "Revista Pós Ciências Sociais" 2014, no. 11(21), pp. 167-184; idem, "É Tudo Energia”..., op. cit.

13 J.G.C. Magnani, O circuito neo-esotérico, op. cit., p. 171. 
This is not a one-way process. We understand that the speed with which the New Age incorporated aspects of popular religiosities, especially Afro-Brazilian, was not the same as the rate at which the Umbanda incorporated aspects from other cultural matrices. This is due to the character of the New Age, as it encompasses a diversity of discourses, abandons a singular system of meanings, and combines symbols from different cultural sources. ${ }^{14}$ Bastide even considers that Umbanda practitioners reading esoteric and even anthropological books implies the displacement of a spontaneous syncretism into a reflected syncretism. ${ }^{15}$

Despite the religious experimentalism, the early New Age synthesis in Brazil did not predominantly include popular religions, especially Afro-Brazilian ones, ${ }^{16}$ whose efficacy of their work is widely recognized. ${ }^{17}$ The changes that can be observed in the Brazilian religious field were implied in displacements, which enabled a more open and emphatic incorporation of the New Age into the Afro-Brazilian religions and vice versa. ${ }^{18}$

In the second half of the twentieth century the production of new symbolic arrangements gave rise to new religious expressions. The articulation between popular religiosities and the New Age became evident, as is the case of the Valley of the Dawn, ${ }^{19}$ and there was also an impact on existing religions, changing their dynamics and representations. Another example of this articulation is neo-shamanism, religious expression formed from the framework of indigenous shamanism. ${ }^{20}$

This phenomenon is also linked to a set of political, social and cultural transformations that occurred in Brazil and enabled the production of these dialogues. It should be recognized that the New Age phenomenon is connected to the issue of counterculture, ${ }^{21}$ which in the Brazilian context is also related to Afro-Brazilian culture..$^{22}$ According to Prandi, it is in the 1960s that the counterculture expanded in Brazil:

They are the years of counterculture, the recovery of the exotic, the different, the original. Enlightened Western youth rebels, takes a liking to Eastern civilizations, their transcendental and occult mysteries (remember the Beatles and the pilgrimage of American and European youth in search of Himalayan gurus). The culture of the other is valued. In Brazil, indigenous culture is valued. Anthropology reshapes ethnography to make indigenist politics. The black culture is valued, especially the black-baiana. Society goes out in search of its roots. [...] Open the doors of perception, go in search of pleasure, the expansion of sensitivity, immediate gratifications for the body and the mind. ${ }^{23}$

${ }^{14}$ L. Amaral, Carnaval da alma..., op. cit.

15 R. Bastide, O sagrado selvagem e outros ensaios, São Paulo 2006.

16 J.R. Prandi, op. cit.

17 Y. Maggie, Medo de Feitiço: Relações entre a Magia e o Poder no Brasil, Rio de Janeiro 1992.

18 A. Oliveira, A Nova Era com Axé..., op. cit.

${ }^{19}$ Idem, A Nova Era com um Jeitinho Brasileiro..., op. cit.

${ }^{20}$ Labate B., A reinvenção do uso da ayahuasca nos centros urbanos, Master's Thesis in Social Anthropology, Unicamp 2000.

${ }^{21}$ L. Amaral, Carnaval da alma..., op. cit.

22 J.R. Prandi, Segredos guardados: orixás na alma brasileira, São Paulo 2005.

${ }^{23}$ Idem, As religiões negras no Brasil: por uma sociologia dos cultos afro-brasileiros, "Revista USP" 1996, no. 28, p. 74. 
We want to emphasize that the understanding of the incorporation of New Age elements in African-born religions and vice versa is part of a broader agenda of social transformations, notable particularly in southern Brazil. ${ }^{24}$ The black movement itself and the struggle for the valorisation of the Afro element in Brazilian culture, as well as the advances of institutional and political arrangements with the state are sociopolitical phenomena that must be emphasized.

In other scenarios, the combination of such practices appears as a "need" in the face of "the new spiritual configurations of the planet, and especially of Brazil," as one interlocutor puts it. The presence of the New Age in the terreiros allows a flow of identities, since even if the religious basis of the supporters is Umbanda, they have what can be understood as freedom to deal with the sacred.

\section{Afro-Brazilian Religions and Alternative Practices in Florianópolis}

There are relevant symbolic elements that constitute the collective imaginary present in Florianópolis. As Maluf ${ }^{25}$ points out, the presence of witches is part of the representations of the local populations. The presence of neo-shamanic practices in the city is also remarkable, which can also be understood as a subset of the New Age. ${ }^{26}$ In the mapping of the temples of the African matrix it was common to talk with Umbandistas who work weekly in the terreiros and who participate in neo-shamanic groups.

At the same time a scenario is presented in Florianópolis where aspects of the African matrix traditions are inserted in these contexts, as is the case of the "umbandaime," houses that practice Umbanda with the consumption of ayahuasca. We became aware of two houses that practice "umbandaime" in the city, although none of our interlocutors reported visiting such spaces, preferring to separate Umbanda from neo-shamanic groups.

The itinerant aspect of the New Age reaches its potentiality in the cities, through the services offered by the holistic centers and by therapeutic, divinatory, and meditative workshops, often professionally organized..$^{27}$ Our interlocutors reported having participated, only in Florianópolis, in workshops in astrology, women's circles, herbal baths, and yoga, among others. Centers offering practices such as astral journeys and past life regression are also common on the "Island of Magic."

Pondering such questions highlights the idiosyncrasies of the field in which we are situated. Although we perceive the incorporation of the New Age ethos as a more

${ }^{24}$ Negros no Sul do Brasil: Invisibilidade e Territorialidade, I.B. Leite (ed.), Florianópolis 1996.

${ }^{25}$ S.W. Maluf, Bruxas e Bruxaria na Lagoa da Conceição: um estudo sobre representações de poder feminino na Ilha de Santa Catarina, "Revista Crítica de Ciências Sociais" 1992, vol. 34, pp. 99-112.

${ }^{26}$ B. Labate, op. cit.

${ }^{27}$ L. Amaral, Carnaval da alma ..., op. cit. 
global phenomenon, ${ }^{28}$ it assumes particular contours in the scenario present in the city of Florianópolis. Even in professional terms in the city this New Age sphere is saturated, making it a very competitive field. Our interlocutors said that although there is demand for such services, the financial return often does not compensate for the investment in this professional area. Some of them even prefer to go to other cities to offer their holistic services.

We emphasize the plurality of experiences that agents produce in this context, with an intense process of combining techniques, devices and resources. According to Maluf, based on research conducted in Porto Alegre and Florianópolis:

The neo-spiritual paths in Brazil run through multiple places: from the psychomic practices in the city to the temples built in the middle of the forest, through the rural communities, the distant ashram, the vegetarian restaurants, the esoteric shops, and also the terreiros and centers of the Afro-Brazilian tradition, along with all kinds of cult of spirits. These places form an itinerary in the city (and beyond) and show the diversity of this experience, characterized by the cohabitation of different forms of religiosity, by their interpenetration, crossing of different religious and spiritual universes and a eclecticism of the lived. ${ }^{29}$

Such combinations, given their dynamicity, always occur in dialogue with existing religious traditions, although the places they occupy in these syntheses may vary. We thus understand that we must also consider the formative aspects of the Afro-Brazilian field itself in Florianópolis to think about these transits. Martins ${ }^{\prime 30}$ discussions about the history of Umbanda in Santa Catarina indicate that until the first half of the twentieth century this was a secretive practice, having officially appeared in the state in 1947 with the inauguration of the São Jorge Guerreiro Spiritist Center, founded in Florianópolis by Maria Ayroso de Barros, known as Mother Malvina. Until 1950 there were still few practicing the Umbanda in Santa Catarina, highlighting names such as those of Mother Didi, Mother Clarinda, and Mother Mima. Only in 1974 was the first Umbanda congress held in Santa Catarina, organized by Father Telles. ${ }^{31}$

There is no denying that the adherents of Afro-Brazilian religions are very few compared to other groups, such as Catholics or evangelicals. "However, AfroBrazilian religions play an important role in the debate about the formation of Brazilian society and in the identity politics of segments of that society." 32

The data that we find on the UNIAFRO website - Union of Black Culture in Santa Catarina - referring to the terreiros of Afro-Brazilian religions in the state, shows a predominance of Umbanda. Of the 86 temples indicated, 70 are from Umbanda. This strong predominance was confirmed by our contacts with researchers who have

${ }^{28}$ S. Guerriero, F. Stern, M. Bessa, A difusão do ethos Nova Era e o declínio de seus estudos acadêmicos no Brasil, "REVER" 2016, no. 16(2), pp. 9-39.

${ }^{29}$ S.W. Maluf, Os Filhos de Aquário no País dos Terreiros: novas vivências espirituais no Sul do Brasil, "Ciências Sociais e Religião" 2003, no. 5(5), p. 166.

${ }^{30}$ G. Martins, Umbanda de Almas e Angola: ritos, magias e africanidade, São Paulo 2011.

${ }^{31}$ Mãe (mother) and pai (father) are the native terms for the priests of the Afro-Brazilian religions, also known as mãe de santo (mother of saint) and pai de santo (father of saint).

${ }^{32}$ L. Duccini, M. Rabelo, As religiões afro-brasileiras no Censo de 2010, [in:] Religiões em Movimento, F. Teixeira, R. Menezes (eds.), Petrópolis 2013, p. 219. 
dedicated themselves to this topic, as well as by the temples that we frequented in Florianópolis. This issue is even more evident from the results presented by the mapping of African-born religions in Florianópolis and its surroundings, in which about 70 different denominations appear, reflecting the practitioners' own perception of Umbanda, as they do not understand it as a homogeneous religion. ${ }^{33}$

For Tramonte the explanation for the predominance of Umbanda in Santa Catarina can be as follows:

The generic denomination of "Umbanda" to the markedly Africanized rituals [...] has its explanation in the light of the testimonies of religious expressing the difficulties faced by AfroBrazilian religions. Umbanda represented a great "umbrella" for its participants, since in the history of Afro-Brazilian religions, this modality was the one that more quickly climbed the steps of social acceptance, as much for its syncretized format, originating from its historical formation, as well as the fact that it included, some decades after its creation, white individuals of middle and high classes in the composition of its members. ${ }^{34}$

We can also affirm on the basis of National Census data that Afro-Brazilian religions do not constitute ethnic religions in this locality, since 1,762 practicants declare themselves as "white," 569 "brown," 481 "blacks," 12 "yellows," and 8 as "Indians." Evidencing this process, $50.2 \%$ of religious leaders are declared "white" or "Caucasian." Umbanda's own historical formation justifies this conjuncture, since although it has characteristics of other religions of African matrix (like Candomblé), it combines elements of Catholicism, spiritism and those of indigenous origins. This is important in what concerns the approach and conversion of followers of other religions to Umbanda. Nevertheless, we emphasize the particularities of the South of Brazil, which has historically denied the presence of the black populations as a constituent element of society and culture.

With these data, we want to point out the profound heterogeneity that exists in the scope of the Afro-Brazilian religions in Florianópolis, especially in the case of Umbanda. This heterogeneity is expressed in terms of self-denomination of the temples, ethnic composition of the adepts, and also the ritualistic and liturgical organization of different temples.

\section{New Age Umbanda: continuities and ruptures}

We focus our analysis on material produced from research conducted in two temples, one of them having self-declared themselves as a "Sacred Umbanda of the New Age" (temple number 1) and another temple that employs a similar concept in their ritualistic activities but has not adopted this denomination (temple number 2).

In terms of organization and cult structure, it is interesting to notice the similarities between the two temples. Both are guided by white women under 50 with

\footnotetext{
${ }^{33}$ I.B. Leite, op. cit.

${ }^{34}$ C. Tramonte, Religião, resistência e história: construção e afirmação da Umbanda em Santa Catarina, "Mouseion" 2014, no. 17(1), p. 91.
} 
graduate degrees. One of them is a lawyer and an artist, the other, a naturopath and therapist. This first aspect draws our attention to the loss of ethnic character of the African derived religions, which in Ortiz's ${ }^{35}$ view occurs not only due to the increasing presence of white people in Umbanda, but also to the changes perceived on a ritualistic level. The historic composition of Umbanda as a Brazilian religion that combines several components helps us understand these characteristics. Another phenomenon would be the presence of the middle class in the religion, ${ }^{36}$ something that has been confirmed by recent census data. ${ }^{37}$

Both temples are situated in neighbourhoods away from the centre of the city, frequently recognized as inhabited by people searching for an "alternative" lifestyle. It is important to indicate that those temples are open to the public and perform their rituals, which ensures that visitors and those who work at those terreiros belong to different social classes.

Both have Facebook pages where they publish their ritual calendars, along with the courses that are related to the religious purposes of the temples. Temple number 1 also indicates the days in which giras with caboclos, marinheiros, exús, pretos velhos and $E r \hat{e} s^{38}$ occur, and other days with reiki and multidimensional therapy. In the process of describing the interior and exterior spaces of the temples, the way temple number 1 described part of its space caught our attention:

We've got an Iansã settlement, that is the regent orixá of the house. ${ }^{39}$ But it is not a material settlement, but an etheric one, done in the astral, with my active participation, holding all the memories, with geometric forms, holographic projections. They are multicolor circles that form some kind of a pyramid, but with circles, so they are in constant movement. They have been placed over all the land of the house when it was being built. So this settlement is immutable, untouchable, it can be known by everyone, but it is indecipherable. Even I, who participated and saw things happening can not describe it. All I can do is to describe it this way. This is our Iansã settlement and our firmness. ${ }^{40}$

This settlement seems to refer to an evident cultural bricolage, in which holographic projections, pyramids and multicolour circles are comprehended as a continuum in relation to Iansã. Although at a first glance the description does not refer to a traditional shape of an Afro-Brazilian cult, marking more ruptures than continuities, it is interesting to realize that the religious syncretism is composed precisely by the creation of new meanings. It is also relevant to point out that methodologically we must consider the way in which the agents perceive themselves in this process. ${ }^{41}$

35 R. Ortiz, A Morte Branca do Feiticeiro Negro, São Paulo 1999.

36 D. Brown, O papel histórico da classe média na umbanda, "Religião e Sociedade" 1977, no. 1(1), pp. 31-42.

37 J.R. Prandi, Os Mortos e os Vivos: uma introdução ao espiritismo, São Paulo 2012.

38 These are the names of some entities that are incorporated by the mediums.

39 The temples are also known as houses (casas in Portuguese).

40 Interview held in August 2017.

41 A. Oliveira, Entre a tradição e a autodenominação: algumas notas metodológicas sobre pesquisas com religião, "Revista Brasileira de História das Religiões” 2018, no. 11(31), pp. 111-121. 
Here we highlight what may be one of the most relevant questions that we found in both temples: the absence of the well-known animal sacrifice, the "cut." If the sacrificial question, mainly the blood one, is considered as a basic tool in Afro-Brazilian religions, especially in Candomblé, ${ }^{42}$ those temples seem to have built a logic that subverts this, creating new meanings in these religions and in the concept of sacrifice.

It is worth emphasizing that different members from both temples declared that "traditional" Umbanda does not do the "cut." There is an idea that the majority of terreiros that are from a "pure" tradition of Umbanda - a tricky term when it comes to religion - does not practice sacrifices. The "cut" appears as something imported from other religious cultures, such as the Jeje-Nagô and Ketu Candomblés, where the practice of animal sacrifice appears as a corruption of the classic Umbanda structure, moulding what the adepts call a "crossed Umbanda." 43

At temple number 2 it is also suggested that the food that is brought to the cults can not contain any product of animal origin. In that way, the food and the festive character are maintained, however re-signified in a distinctive context, where the $a x e^{44}$ is sought in other elements. This subject also came up when questions were asked about the food that is usually offered to the entities. We received the following answers:

Temple number 1:

Oxalá: wheat, italian grape, lime-orange;

Oyá: surinam cherry;

Exú: lime, strawberry, apple, pepper, cornflour;

Iemanjá: plums, white custard pudding; Iansã: orange, strawberry, grape, peach;

Oxóssi: all kinds of fruits, starfruit;

Ogum: mango;

Preto velho: coconut, coffee, palm

Obaluaê: popcorn without salt or oil.
Temple number 2:

Oxalá: white corn kernels, flowers and candles; Iemanjá: white custard pudding;

Ogum: peanuts, mango, pomegranate;

Oxóssi: 7 kinds of fruits;

Oxum: corn kernels;

Iansã: pumpkin with corn;

Xangô: okra;

Preto velho: bean tutu;

Exú: crumbs;

Erês: natural candies.

We can observe the replication of certain elements, such as the white custard pudding to Iemanjá, or mango to Ogum; however, there is clearly an astonishing vein of inventiveness in the process of choosing the food to be offered to the gods. At temple number 1 it is clearly declared that they use "fruits and fruits at large. Except for Oxalá, for whom sometimes we offer wheat as flour or bread." ${ }^{45}$

${ }_{42}$ R. Motta, Sangue sobre a Terra: Notas sobre o Sacrificio Afro-Brasileiro, "Pasárgada" 1993, no. 2(2-3), pp. 86-89; idem, Le Sacrifice Xangô à Recife, "Social Compass" 2003, no. 50(2), pp. 229-246; idem, Santidade, Sacrificio, Imagem e Festa: Crenças e Ritos Básicos da Tradição Afrobrasileira, "Revista do Instituto Arqueológico, Histórico e Geográfico Pernambucano” 2011, no. 64, pp. 11-49.

${ }_{43}$ D. Rainho, Conhecendo a Umbanda - Dentro do Terreiro, São Paulo 2018.

${ }^{44}$ Axé can be translated as "energy," or "vital force," and is considered the basic element for the realization of rituals in Afro-Brazilian religions. In Candomblé the presence of the axé is linked mainly to the blood, being obtained through the ritual sacrifice of animals.

${ }^{45}$ Interview held in August 2017. 
Those characteristics allow us to perceive a movement of approximation and distance in relation to tradition, which in a double movement shows that both temples are included in the Afro-Brazilian tradition, but at the same time marks the social differentiation that produces a new aesthetics and a new world ethic. Even at the mediumic consultations the talk with the entities assumes a deeply psychological aspect, something quite characteristic of the New Age therapies, ${ }^{46}$ in which the answers given by the entities point to a process of self-knowledge.

Combined with that, in temple number 1, properly decorated with coloured mandalas, we found intense activity in the courses being offered, concerning Umbanda as well as alternative therapies like reiki. The image of this specific terreiro looks like holistic centres common in the New Age movement that are marked with a variety of alternative workshops. ${ }^{47}$

In one of the courses offered by this temple, called "Consciousness Awakeness," the leader of the centre presented herself as a holistic therapist with an education in Umbanda theology, occupying the role of the "facilitator" of the course. As a summary of the course the following is shown:

What is my mission? The individual at New Age and its role.

Am I Being or am I just standing? Be proactive or reactive.

Our goal is that the participants are able to promote an intimate change, comprehend their mediumity, as well as maturing according to their own life purpose and developing trust to assume control of their own journey, to join in work that uses their mediumic capacities, such as acting in groups of people that help incarnates, as well as general therapeutic works.

Target audience: Therapists, new or already active mediums, people interested in self-knowledge and energetic healing. ${ }^{48}$

The content of the course for the first meeting is: "Introduction to the spiritual world: life after the death; Similarities between the Astral and the Physical plane; Spiritual plane; Karma; Astral traveling - Projection of the consciousness; Mediumity, preparation, the necessity of study; Obstacles and challenges to the manifestation of the spirits and the neutralization of acts originated from morally inferior spirits." For the second meeting: "Knowing the Chakras; Captation and projection of chakras; Exercises that will open the doors of mediumic facultities with responsibility and safety; How to protect yourself from spiritual attacks; Role of the altars, images, stones, fragrances (incenses and essences), cleaning and energetic baths; The processes necessary to the Spiritual Magnetic Passes - Self-application and application on other people - in person and at long distance; Works of energetic cleaning of people and places," concluding the course with magnetic passes in a group.

The focus on the techniques is another recurrent characteristic of the therapies used in the New Age universe, ${ }^{49}$ and in this context they arise in a way that through the recurrent use of such techniques it would be possible to achieve self-knowledge.

\footnotetext{
46 A. D'Andrea, O self perfeito e a nova era, São Paulo 2000.

${ }^{47}$ L. Amaral, Carnaval da alma ..., op. cit.

${ }^{48}$ Information available on the terreiro Facebook page.

49 J.G.C. Magnani, Mystca Urbe..., op. cit.
} 
Last but not least, it is necessary to emphasize the articulations between charity and the offering of free alternative therapies and courses to the community. This is an element of the alternative therapies used especially in Umbanda. A central part of the process that enables the adepts to perceive more continuities than ruptures between the "traditional" Umbanda and the New Age, understanding that the activities integrate charity, one of the foundations of Umbanda in spiritual terms. For the participants, a polarization or even a duality between the two universes does not seem to exist.

Even though it is not possible to go deeper into the debate about this question in this short paper, we comprehend that those shifts in ritualistic and ethic levels experienced at both temples reflect the incorporation of a New Age ethos that shows itself in more or less explicit manners.

\section{Final words}

The literature approaching questions concerning Afro-Brazilian religions is quite wide, and a significant part of it has been trying to apprehend the dynamic movement of the religions and how they engage in dialogue with other cultural traditions. When dealing with fieldwork done in religions of African descent, we must have in our view that particular occasions and the contact with certain interlocutors mark the construction of the relationships built. ${ }^{50}$ In a continuous process of awareness and recognition that our logic as researchers differ from "native" logic, we searched for the construction of a reflection that reveals specific characteristics of this field that has yet to be further explored.

This work is a brief initial sketch that looks to understand the relations between Umbanda and New Age in the context of the city of Florianópolis. We believe that it brings a relevant contribution to the field, as we have explored questions that have not been much debated. Curiously, in both temples there is no explicit reference to esoteric practices inside Umbanda itself, a category comprehended as a key when thinking about the dialogue between the Afro-Brazilian religions and the New Age phenomenon. ${ }^{51}$ That provides us with clues for thinking that the these practices are still in the process of construction, looking for new categories in which the agents can identify themselves, even if that idea is already expressed by the denomination "Sacred Umbanda of New Age."

Also at the first temple, we found a recursive utilization of alternative therapies, comprehended not as something opposed to or aside from the "traditional" practices of Umbanda, but as a continuum, by having the comprehension by the adepts that those practices would have the same spiritual basis.

Even though one of the aspects that caught our attention is the absence of the sacrifice, it is interesting to realize that the process of eliminating this kind of practice is

\footnotetext{
${ }^{50}$ V.G. Silva, O Antropólogo e sua magia, São Paulo 2006.

${ }^{51}$ S. Guerriero, Novas configurações das religiões tradicionais: ressignificação e influência do universo Nova Era, "Tomo" 2009, no. 14, pp. 35-53; A. Oliveira, A Nova Era com Axé..., op. cit.
} 
not something new for Umbanda. ${ }^{52}$ What gains relevance here is the "cut" being fully eliminated from the rituals and replaced by new elements, re-signifying the idea of sacrifice common to Afro-Brazilian religions, producing new ethics and new aesthetics. Motta, in analysing the transformations of the Afro-Brazilian religions in Recife in recent years, points out that the Umbanda Branca rejected it with emphasis, considering it a "barbarian" rite. Motta ${ }^{53}$ also points out the return of the "cut" in many of these temples in recent years, which runs counter to certain "evolutionary theories" about the Afro-Brazilian cults, although there are differences in relation to how such sacrifices were performed in more "traditional" temples. ${ }^{54}$

It should be acknowledged that since the New Age phenomenon is not an organized movement, ${ }^{55}$ distinct Umbanda temples might assume only the characteristics that they want to select from it. In this sense, a scenario of "exacerbated syncretism" could lead to the weakening of the importance of the religion's origins.

It is possible to infer that these types of practices gain greater resonance in the "alternative circuit" of Florianópolis, incorporating elements of an ethos that is widespread in the local culture and that already involves the collective imaginary. The data analysed here allow us to perceive the plasticity and heterogeneity of Umbanda, and its potential to produce dialogues and meanings in the process of experiencing the sacred within its agents.

\section{References}

Amaral L., Carnaval da alma: Comunidade, essência e sincretismo na Nova Era, Petrópolis 2000.

Amaral L., Sincretismo em movimento: o estilo nova era de lidar com o sagrado, [in:] A nova era no Mercosul, M.J. Carozzi (ed.), Petrópolis 1999, pp. 47-79.

Amaral L., Um espírito sem lar: sobre uma dimensão nova era da religiosidade contemporânea, [in:] Circuitos infinitos, O.G. Velho (ed.), São Paulo 2003, pp. 27-58.

Bastide R., O sagrado selvagem e outros ensaios, São Paulo 2006.

Brown D., O papel histórico da classe média na umbanda, "Religião e Sociedade" 1977, no. 1(1), pp. 31-42.

Carneiro J., Carneiro E., Umbanda Esotérica não é Esoterismo na Umbanda, "Revista Brasileira de História das Religiões" 2017, no. 10(28), pp. 113-124.

D’Andrea A., O self perfeito e a nova era, São Paulo 2000.

Duccini L., Rabelo M., As religiões afro-brasileiras no Censo de 2010, [in:] Religiões em Movimento, F. Teixeira, R Menezes (eds.), Petrópolis 2013, pp. 219-234.

Guerriero S., Novas configurações das religiões tradicionais: ressignificação e influência do universo Nova Era, "Tomo" 2009, no. 14, pp. 35-53.

Guerriero S., Stern F., Bessa M., A difusão do ethos Nova Era e o declínio de seus estudos acadêmicos no Brasil, "REVER" 2016, no. 16(2), pp. 9-39.

52 J.R. Prandi, Os Mortos e os Vivos..., op. cit.

${ }^{53}$ Ibidem.

${ }^{54}$ Despite the relevance of the theme of sacrifice in Afro-Brazilian religions, it would be far from the focus and scope of this article to go further into this.

55 L. Amaral, Carnaval da alma ..., op. cit. 
Labate B., A reinvenção do uso da ayahuasca nos centros urbanos, Master's Thesis in Social Anthropology, Unicamp, 2000.

Leite I.B., Territórios do Axé: religiões de matriz africana em Florianópolis e municípios vizinhos, Florianópolis 2017.

Maggie Y., Medo de Feitiço: Relações entre a Magia e o Poder no Brasil, Rio de Janeiro 1992.

Magnani J.G.C., Mystca Urbe: um Estudo Antropológico Sobre o Circuito Neo-Esotérico na Metrópole, São Paulo 1999.

Magnani J.G.C., O Brasil da Nova Era, Rio de Janeiro 2000.

Magnani J.G.C., O circuito neo-esotérico, [in:] As religiões no Brasil, F. Teixeira, R. Menezes (eds.), Petrópolis 2006, pp. 161-173.

Martins G., Umbanda de Almas e Angola: ritos, magias e africanidade, São Paulo 2011.

Maluf S.W., Bruxas e Bruxaria na Lagoa da Conceição: um estudo sobre representações de poder feminino na Ilha de Santa Catarina, "Revista Crítica de Ciências Sociais" 1992, vol. 34, pp. 99-112.

Maluf S.W., Os Filhos de Aquário no País dos Terreiros: novas vivências espirituais no Sul do Brasil, "Ciências Sociais e Religião" 2003, no. 5(5), pp. 153-171.

Motta R., As variedades do espiritismo popular na área do Recife: ensaio de classificação, "Boletim da Cidade do Recife" 1977, no. 2, pp. 97-114.

Motta R., Le Sacrifice Xangồ à Recife, "Social Compass” 2003, no. 50(2), pp. 229-246.

Motta R., Sangue sobre a Terra: Notas sobre o Sacrificio Afro-Brasileiro, "Pasárgada" 1993, no. 2(2-3), pp. 86-89.

Motta R., Santidade, Sacrifício, Imagem e Festa: Crenças e Ritos Básicos da Tradição Afrobrasileira, "Revista do Instituto Arqueológico, Histórico e Geográfico Pernambucano" 2011, no. 64 , pp. 11-49.

Motta R., Umbanda, Xangô e Candomblé: crescimento ou decomposição?, "Ciência \& Trópico" 2001, no. 29(1), pp. 175-187.

Negros no Sul do Brasil: Invisibilidade e Territorialidade, I.B. Leite (ed.), Florianópolis 1996.

Oliveira A., A Nova Era com Axé: umbanda esotérica e esoterismo umbandista no Brasil, "Revista Pós Ciências Sociais" 2014, no. 11(21), pp. 167-184.

Oliveira A., A Nova Era com um Jeitinho Brasileiro: O Caso do Vale do Amanhecer, "Debates do NER" 2011, no. 12, pp. 67-96.

Oliveira A., "É Tudo Energia” - A Nova Era e a Umbanda em diálogo, "REVER” 2016, no. 16(2), pp. 92-107.

Oliveira A., Entre a tradição e a autodenominação: algumas notas metodológicas sobre pesquisas com religião, "Revista Brasileira de História das Religiões" 2018, no. 11(31), pp. 111-121.

Ortiz R., A Morte Branca do Feiticeiro Negro, São Paulo 1999.

Prandi J.R., As religiões negras no Brasil: por uma sociologia dos cultos afro-brasileiros, "Revista USP" 1996, no. 28, pp. 64-83.

Prandi J.R., O Brasil com Axé: candomblé e umbanda no mercado religioso, "Estud. av., São Paulo" 2004, no. 18(52), pp. 223-238.

Prandi J.R., Os Mortos e os Vivos: uma introdução ao espiritismo, São Paulo 2012.

Prandi J.R., Segredos guardados: orixás na alma brasileira, São Paulo 2005.

Rainho D., Conhecendo a Umbanda - Dentro do Terreiro, São Paulo 2018.

Silva V.G., O Antropólogo e sua magia, São Paulo 2006.

Terrin A.N., Nova Era: A religiosidade do pós-moderno, São Paulo 1996.

Tramonte C., Religião, resistência e história: construção e afirmação da Umbanda em Santa Catarina, "Mouseion" 2014, no. 17(1), pp. 89-97. 